\title{
Embraer and the growth of the Brazilian aircraft industry
}

\author{
Anne-Marie Maculan \\ Faculty of Engineering, \\ Federal University of Rio de Janeiro, \\ CP 68507. 21945-970, Rio de Janeiro, Brazil \\ E-mail: amaculan@pep.ufrj.br
}

\begin{abstract}
The growth path of the Brazilian aerospace industry and its competitiveness in international market are examples of a successful process of 'catching up'. However, the Brazilian aviation industry needs to deal with various vulnerability factors. The paper presents a short retrospective of the growth of the Embraer company. We describe the company's activities in its first years, the growing problems in the 1980s that led to privatisation in 1994 and Embraer's behaviour after privatisation. Particular attention is given to its technology and marketing strategy. Finally, we discuss the current challenges to the company's ability to compete.
\end{abstract}

Keywords: Embraer; aerospace industry; Brazil; internationalisation.

Reference to this paper should be made as follows: Maculan, A-M. (2013) 'Embraer and the growth of the Brazilian aircraft industry', Int. J. Technology and Globalisation, Vol. 7, Nos. 1/2, pp.41-59.

Biographical notes: Anne-Marie Maculan is an Associate Professor, at the Production Engineering Program of COPPE, Federal University of Rio de Janeiro, Brazil. She received her $\mathrm{PhD}$ in Socioeconomics at University of Quebec at Montreal. She has been a Consultant for the Ministry of Science and Technology, World Bank and Brazilian Federal or State Agencies for research and innovation. She has published several papers on Brazilian science and technology policy. Her main areas of academic interest include: technology transfer, academic entrepreneurship and the role of research institutions in the local innovation system.

\section{The origins}

The Brazilian aircraft and aerospace industry has a total output of US $\$ 6.7$ billion in 2010 (AIAB, 2010). $90 \%$ of the value produced come from the civil aviation industry, $8.5 \%$ from the defence sector and $0.5 \%$ corresponds to the aerospace sector. Exports represent $80 \%$ of sales.

Embraer, the principal company, is responsible for around $80 \%$ of the activity in the sector. The industry is made up of 40 companies, of which 18 participate directly in activities related to the assembly and maintenance of aircraft (IBGE, 2009). Embraer, along with Helibras, are the two largest firms in the industry. The others firms are small suppliers of components or parts. 
Helibras is currently controlled (76\%) by Eurocopter. The government of the State of Minas Gerais has a small share (12\%) in the company. The company manufactures and exports helicopters to various countries in South America. In addition, it provides post sales support services and maintenance. Helibras is the leader in the Brazilian turbine helicopter market with $49 \%$ of the civilian market, $81 \%$ of the government market and $66 \%$ of the military market. The Brazilian market has grown by $58 \%$ in recent years and today there are 1,200 helicopters in operation (3\% of the worldwide fleet). Helibras is expanding its activities as the result of a request made by the government in 2008 for the manufacture of the heavy helicopter EC-725. The company is currently negotiating the share of the domestic industrial chain in the project, as part of a deal to respond to the calls for the transfer of technology to local companies that supply parts and components.

Embraer was created in 1969 by the Brazilian government to manufacture small aircraft for military use. By the first decade of the XXI Century, it has transformed itself into an internationally recognised manufacturer that currently has around $45 \%$ of the worldwide market for the regional aviation and $16 \%$ for executive aircraft. The company is the second largest exporter in Brazil and has 17,149 employees of which 95\% are based in plants of the company in Brazil. Therefore, the performance of Embraer may be regarded as essentially equal to the performance of the whole Brazilian aircraft industry.

With a 40 years experience in the design, manufacture, sale and post sale of aircraft, Embraer has so far manufactured around 5,000 aircraft and its client base is made up of governments and aviation companies in more than 60 countries. Embraer distinguishes itself from the vast majority of industrial companies in Brazil in its capacity for innovation and its ability to compete internationally and to export high technology goods.

An analysis of the development of the aviation industry and of the growth path of Embraer leads to ask which are the factors that sustain this positive performance. How was a small state-owned company, with a strong military culture, transformed into a leading company in the international aircraft market? How Embraer, which produced only few aircraft parts, managed to organise a complex network of domestic and international suppliers? How was Embraer able to negotiate a majority partnership association with a Chinese state company, and risk partnerships with large international corporations for the development of the electronics and hydraulic systems, brakes and wings for its projects? How was Embraer able to survive in an industrial sector that was severely affected by political events such as the September 11, 2001 attacks, the peaks and valleys of the airline industry and passenger traffic and the 2008 worldwide financial crisis? What were the challenges that had to be overcome in the past and what challenges remain to be confronted?

The first part of this paper presents a brief retrospective of the development of the civil aviation industry in Brazil followed by a description of the political and economic context in which Embraer was created. We describe the company's activities in its first several years, as well as the growing problems in the 1980s that, by the beginning of the 1990s, almost led to bankruptcy, and eventually led to privatisation in 1994. The third part offers a detailed examination of Embraer's behaviour after privatisation, with particular attention to its technology and marketing strategy. Finally, we discuss the current challenges to the company's ability to compete. In conclusion, we comment on the impact of industrial and technological policies of the last decade on the growth of Brazil's aviation and aerospace industry. 


\subsection{Brazil's aviation industry from the 1930s to the creation of Embraer}

The history of Brazilian aviation goes back to Paris with Santos Dumont in the first decade of the 20th century. He made the first European public flight of an airplane on October 23, 1906. His '14-bis' was the first fixed-wing aircraft to take off and successfully fly. In 1908, Santos Dumont started working with the Clement-Bayard Company to build the 'Demoiselle 19'. They planned a production run of 100 units, built 50 and sold only 15 . It was the world's first aircraft series production.

There were several attempts to manufacture airplanes in Brazil between 1930 and 1950. The Aeronautica Ypiranga Company was created in 1931, but failed to get past the prototype stage. The Company of Navegaçao Costeira manufactured several airplanes on a commercial scale in 1935. The National Company of Navigaçao Aerea produced two airplanes with the Ypiranga project, but concluded its activities in 1948. In 1942, the Paulista Aeronautica Company used the Technological Research Institute of the State of São Paulo to design the Paulistinha, a single engine airplane widely used by the Brazilian Armed Forces and civilian flying clubs. The Paulistinha was exported to Argentina, Paraguay, Uruguay, Chile, the USA, Portugal and Italy. Few years later, the Neiva Company manufactured the Seneca II and III under license from Piper Aircraft (USA) to supply government orders. In 1971, this company began to produce the Ipanema - an Embraer's project. The company is now part of Embraer.

\subsection{The first steps toward a domestic aviation industry: 1960-1980}

During the 1950s, the Ministry of Military Aviation created the Aeronautical Technology Institute (ITA) and the Aeronautical Technology Center (CTA), two institutions that can be considered the embryos of Embraer. The political-military doctrine of the governments at the time planned to create an integrated aviation infrastructure for common use by the civil aviation and military sectors and laid the foundations for an aviation industry in Brazil. The research activities of CTA and ITA were organised to assure the technological development of the industry (Forjaz, 2003).

The Ministry of Military Aviation worked to integrate the institutions of higher learning and research and the private companies to guarantee the technological development of the aviation industry. The ITA was supported by an agreement with the Massachusetts Institute of Technology and the California Institute of Technology. The CTA was established to make sure that the aviation sector would engage in self-sustaining R\&D (Pereira, 2007). These activities in Civil Aviation would lead to the training of engineers specialised in electronics, mechanics and aviation infrastructure. These two organisations formed the institutional foundation to promote the development of Brazilian aeronautical industry.

The Military Ministry of Aviation policy made the training of human resources, capable of absorbing the technological knowledge available in the international market, and of searching for appropriate solutions for the domestic market. The mission was to carry out scientific and technical research, to collaborate with other research institutions and to cooperate with industry. The CTA had to be able to use some of the emerging technologies from abroad, to leverage local industry and to encourage the creation of new firms.

The Bandeirante - one of the first products of the CTA - began to fly in 1968. Unlike the new generation of jet or turboprop aircraft available on the international market, that 
required longer airport runways, the Bandeirante could land or take off on any runway. It was compatible with the precarious nature of airport infrastructure, particularly in areas where the agricultural frontier was expanding and into the Amazon region.

During the 1960s, other companies were created. They all had strong connections to the military sector. That was true of Avibras, the company that developed rockets for the Brazilian space programme as well as of Helibras, founded in 1971, to manufacture helicopters under license of the French company Aerospatiale.

\section{Industrial and technology policy for the aviation sector}

Brazil's aviation industry is a good example of a successful process of 'catching up'. It produces and exports high technology goods and plays a strategic role in the transportation infrastructure of Brazil. Government support takes two main forms: financing investment, exports and research and buying aircrafts for military purpose. The development of the aviation industry was considered essential by successive governments in Brazil to assure the economic growth and guarantee military security given the size of the country.

In the 1960s and 1970s, the industrial policy project was to turn Embraer the principal instrument for the structure and development of the sector. The state was the owner, developer and buyer of the industry. However, the long (1982-1994) period of severe economic instability, that occurred as a consequence of the external debt crisis, took from the government many of its tools of industrial policy. Public investment capacity and the ability to purchase eroded over the years.

After 1995, the government worked to recover its ability to define the goals of industrial policy. But the economic environment was different than that of the 1970s when state-owned companies were the preferred instruments of the industrialisation process. The privatisation of state-owned companies, the internationalisation of the economy, the growth in the ability to export and the liberalisation of imports combined to create a new scenario.

Currently, this industry is one of the few sectors that exports high technology goods. The majority of Brazil's exports are manufactured goods with low or medium technological content. High technology products, which in 2000 represented $12.4 \%$ of exports, amounted to only $4.6 \%$ in 2010 . The share of the aeronautics industry in exports declined from $3.1 \%$ to $2.3 \%$ and imported inputs represented on average $76 \%$ of the products exported (MDIC).

The Brazilian Institute for Geography and Statistics (IBGE) has identified 40 companies that are active in the sector of which 18 are dedicated to the assembly, maintenance and repair of aircraft (IBGE, 2009). There is a limited number of small companies that gravitate around Embraer by virtue of their role as suppliers. Studies by the National Economic and Social Development Bank (BNDES) point out the fragile nature and limited productive capacity of this supply chain. These companies were not able to become technologically advanced like Embraer, or to take advantage of the opportunities of delocalisation of production like Helibras. These two companies were able to realise the process of active learning, while other small companies were simply capable of passive learning (Viotti, 2002).

In 2008, the international financial crisis hit the small companies particularly hard since their principal clients reduced the final demand. The companies providing 
maintenance services were least affected since there income is not directly linked to the level of production of aircraft. Maintenance services are necessary under any circumstances, although the execution of these services has the effect of postponing the acquisition of new models of aircraft (ABDI-UNICAMP, 2009). This is why the support of this sector became an important goal of the government, outlined in the 2008 Production Development Policy (MDIC).

The BNDES (2008) has developed two types of financing programmes for the sector. The 'Pro Aviation Company Program' finances the development of products and services for aviation in the risk partnership model, so that small companies will be able to invest in production capacity and innovation. The intention is to promote industrial modernisation and strengthen the productive chain in the aviation industry. A second programme is designed to finance exports and benefit principally two companies: Embraer and Helibras.

The support for technological development is provided through financing of research. The introduction of the Sectorial Funds system by the Ministry of Science and Technology brought stability to the public financing of research after two decades of sharp decline. In 2000, a Sectorial Fund - CT-Aeronautica - was created for the aeronautics sector. Despite this significant improvement, the funding from the Sectorial Fund has been considerably limited by the policy of contingencies imposed by the government to control the public deficit.

Moreover, the set of research institutions that make up the system of research is limited too. The impact of projects like those of the CTA in the 1960s is hard to find today. The research programmes are spread in small projects among various institutions. Investments in R\&D by Embraer itself are greater than those financed publicly. The situation is even more precarious in the aerospace industry despite the creation of the Brazilian Aerospace Agency in 1994.

\section{The first stage: 1969-1994 - from the creation to the privatisation of Embraer}

\subsection{The origins of Embraer}

Empresa Brasileira de Aeronáutica - Embraer - was created during the last days of 1969 by the Brazilian government as the first element in a strategic-military project to set up the aviation industry. The government required that State be the principal and controlling shareholder (with $51 \%$ of the shares) and the company be subject to the direct control of the Ministry of Military Aviation. The decision was taken in the political context strongly marked by concerns about national security and was consistent, too, with the import substitution model of economic development (Goldstein, 2002). This model was characterised by commercial protectionism, by the strong presence of the State in the strategic industrial sectors and by the search for technological autonomy.

Embraer is part of a set of companies, all created in the " $60 \mathrm{~s}$, to provide support and leadership in high technology industry sectors (data processing and telecommunications) and in basic inputs (steel and energy). For the company to start operations, two complementary decisions were essential: limitation to imports of foreign goods that would compete with the local production and orders from the Brazilian Air Force (FAB). This helped make Embraer economically viable during the first ten years of its existence. 
With regard to technology, the CTA and the ITA were the two principal institutions of engineering research that supplied the knowledge base and provided highly qualified human resources. The first president of the company was an engineer from ITA, Ozires Silva, who had been in charge of the development of the Bandeirante aircraft prototype, the production of which was the principal reason for the creation of the company. In fact, not only the president of the company, but many of its engineers and technical staff, had been trained by ITA or were researchers at the CTA. Embraer was a natural spin off of the CTA.

Meanwhile, soon after its creation, the company began to diversify its sources of technology. Embraer decided to obtain technology by negotiating with foreign firms. The company signed important agreements for cooperation in technology, that were indispensable for beginning industrial production.

\subsection{The start of production}

The armed forces needed an all-purpose airplane to be used for cargo and passenger transportation. They asked for an airplane that had low operating costs and the capacity to link remote regions that had little infrastructure. A team from CPA was given the task of developing this aircraft. Thus, the Bandeirante was born and was the first airplane to be sold by Embraer. Mass production of the aircraft was made possible by an initial order of 60 aircraft from the Ministry of Military Aviation, later followed up by an order for more than 200 units for military transportation. The turboprop EMB-110 Bandeirante had a load capacity of 15-21 passengers for civil or military use. The original programme called for the production of two Bandeirantes per month. The last Bandeirante was produced in 1990. All in all, more than 500 aircraft were manufactured.

Embraer proved to be capable of successful technical learning. Between 1969 and 1992, the company was able to develop and manufacture a dozen other models. Its process of technological competence building incorporated various kinds of knowledge, acquired from international aircraft manufacturers in addition to the internal R\&D activities and joint projects with the CTA. The company systematically applied to transfer of technology, imports of parts and components, alliances and partnerships with foreign companies. Embraer acquired experience and knowledge through learning by doing, learning by adapting and learning by searching.

Its marketing strategy incorporated two important features: the emphasis on versatility in military or civilian use of the aircraft and the potential for exports to niche markets in the civil aviation and military sectors. Embraer achieved significant commercial performance. In the 1970 s, the company emerged internationally with the successful sales of the Bandeirante, the Ipanema, and later the turboprop Brasília and Tucano, a military flight-training aircraft. Its share of the international market for regional civilian aviation - especially in the category of 10-20 carrying capacity aircraft - increased rapidly.

Embraer started exporting the Bandeirante to the USA in 1975. There were only three other companies manufacturing 10-20 passenger aircraft suitable for the regional (commuter) market: Fairchild, Beach and de Havilland. Because of its low acquisition cost, modest operating costs and favourable financing terms, the Bandeirante was a success in the North American market. In 1982, the Bandeirante represented $62 \%$ of North American imports of aircraft in the 10-20 seat segment, and it served $32 \%$ of this market. 
Shortly thereafter, Embraer developed two other airplanes: the Xavante and the Ipanema. The Xavante was based on technology acquired from the Italian company Aermacchi and equipped with Northrop engines. Production began in 1971 and continued until 1981. It immediately found an export market in Latin America and Africa. Work on the Ipanema began in 1971 in cooperation with an Italian firm and is still produced today. More than 1,000 units were sold by Neiva Company, a subsidiary of Embraer. Today, the plane flies on ethanol. The Xingu was the first pressurised airplane developed and produced by Embraer. Although it was not a commercial success, it provided the experience necessary for the later development of the Brasilia.

The development and manufacture of the Bandeirante provided Embraer with the experience and knowledge necessary to design the EMB-120 Brasília, a larger, faster and pressurised aircraft. The Brasília was designed for the international market, since 1985 it has been exported and was manufactured until 1998. It was replaced by the ERJ130-145 generation aircraft. By this time, Embraer had accumulated sufficient experience and competences to become a recognised commercial partner for many foreign airlines.

In the military sector, the need to overhaul the FAB fleet led to the development of the training and attack aircraft EMB312 Tucano. This project was financed by the Ministry of Military Aviation at the end of the decade of the 1970s. The aircraft is still being produced today after undergoing a number of improvements and is currently used by a 14 air forces around the world.

\subsection{The roots of Embraer's competitiveness in the decade of the $1980 \mathrm{~s}$}

Up through the middle of the decade of the 1980s, the Embraer's competitivity was based on the projects conceived to attend to the identified niches in the civilian market as well as in the military market. This strategy was successful. The company got a positive image in the international market and proved to be capable of designing a business strategy that integrated technological performance, marketing and technical assistance features that were appropriate for both the domestic and international markets.

The government was undoubtedly the largest costumer of the company throughout this period. Government support took different forms: orders, free transfer of technology for the Bandeirante development from the CTA, the capitalisation of the company through contributions from other public companies and tax exemptions on imports of parts and equipment. The government met the financial needs of the company until the beginning of the 1980s, when the external debt crisis drastically reduced the available funds for public financing.

According to Dagnino (1993), Embraer did not base its technology strategy exclusively on the import of 'technology packages'. On the contrary, because of its military origins, the company desired technological autonomy, which was understood to be a process of learning, acquiring skills and training. This was made possible by the acquisition of technologies identified as being essential for the support of industrial production and that allowed the occupation of both domestic and international market niches. Along with the acquisition of technology and partnership agreements, there were significant investments in internal and external research. The essential goal was the mastery of technology.

Embraer rapidly set out to develop a truly competitive strategy that combined the use of technology, identification of market niches and experience in organisation of production. The 'learning by doing' and 'learning by adapting' strategies included efforts 
to accumulate skills that were not related exclusively to technological research, but were also applied to marketing, negotiating ability and organisation of the production process. The agreements with international partners, like Aermacchi for the manufacture of the Xavante, and with Piper Aircraft to produce the Seneca, were also viable economically because of the trade barriers protecting the domestic market. The negotiating experience with large international companies was particularly valuable for purchasing complex technological components from McDonnell Douglas and Boeing companies, for defining sales terms with foreign airlines and for providing post sale maintenance services for the exported aircraft.

The company set up a network of international and domestic suppliers composed of a 400 companies that manufactured a wide range of components. Even today, Embraer is one of the 20 largest Brazilian importing companies. The principal countries supplying inputs are:

- USA: light airplane kits, sheet aluminium, connectors, plates of stainless steel and other alloys, nuts and bolts and screws, valves, avionics, engines

- Great Britain: engines

- France: parts and avionics components

- Italy: kits for military aircraft, pieces and components

- Canada: engines.

\subsection{The threats of indebtedness and lower productivity}

During the 1980s, the interruption of industrial policies and the elimination of the financing mechanisms that supported the sales of aircraft and weakened the performance of Embraer. Towards the middle of the 1980s, Embraer faced a series of difficulties that almost led to its bankruptcy until it was privatised in 1994.

The aviation industry needs heavy investments in research and technology. Government funding for R\&D gradually declined. There was a degradation of research capability of the CTA due to reductions in public funding for science and technology. Embraer was forced to internalise the costs of $R \& D$ and take on additional research activities that had thus far been totally financed by the government. This led to a deterioration in the process of technological learning and knowledge accumulation.

The philosophy of Embraer, which at the time of its creation was linked to the full development of aerospace technology, driven by strategic-military factors, took on a new direction, based principally on securing a market niche. Embraer as a state-owned company did not have access to public financing of the BNDES. The absence of credit for exports was prejudicial to the ability of the company to compete on the world market. Financing was not restored until 1993 when the Export Financing Program (PROEX) was created (Cassiolato et al., 2002).

The Brasília aircraft programme had already begun to show signs of deterioration. The commercial version of the airplane, with the capacity to transport up to 30 passengers, was practically obsolete, since Embraer (as its strongest competitor the Canadian company Bombardier) was already developing a new aircraft with the technology of jet engines. 
The AMX aircraft project was facing the same problem. The aircraft was not considered to be high technology at the time. It was directed for military use, and took place at a time when there was a slowdown in military orders with the cuts in budgets for the overhaul of the military fleets.

The organisational and management structure of the company and the way that it had been supported by the government, from the start, now became barriers to its ability to compete internationally. Further, when Brazil ended up being a democracy again, the public policies, that supported the modernisation project conceived by the military governments, had been exhausted. The organisational structure that resulted from its military function led to not very realistic corporate decision-making, less efficient production and growing inability to sell its products in domestic and international markets.

The culture of the company was strongly influenced by technical and nationalistic values. If, on the one hand, these factors guaranteed a high degree of unity and idealism on the part of company employees, on the other, they made the evolution of more effective and competitive management of production factors and financial resources more difficult (Bernardes, 2003). Problems related to the extreme verticalisation of the production process were evident. The multiple departmental divisions were highly individualised and hardly integrated into the whole of the company. The consequence was an organisational burden that made the company less dynamic.

In the international environment, there was a frankly unfavourable outlook as a result of the worldwide recession in the civil aviation market and the decline in demand for military aircraft. During the first few years of the 1990s, a serious financial crisis occurred in the company, due principally to the higher cost of imported components.

Despite the crisis, Embraer maintained a reasonable level of production, and from the 1980s through to its privatisation in 1994, the company produced more than 2,600 aircraft. But the total debt owed by Embraer amounted to around US \$1 million. The government set up a company restructuring programme shortly before privatisation, with a loan of more than one half million dollars for the partial repayment of debts. After three years of budgetary cuts, Embraer was included in the national privatisation programme.

\section{The privatisation of Embraer}

After six postponements, the Embraer auction was held on December 7, 1994 at the São Paulo Stock Exchange. After privatisation, the company continued to face the unfavourable realities in the international aircraft market. Embraer accumulated debts of around US \$400 million with income of around US \$250 million and losses of US $\$ 330$ million. The principal sources of earnings for Embraer at that time were the Brasília and the AMX aircraft, and both were experiencing declining market value.

The decision to privatise Embraer was met with resistance from the nationalist sectors and the Brazilian Armed Forces, but it saved the company from bankruptcy. In 1992, Ozires Silva, who had been the first president of the company until 1986, was called a second time to head the company, to organise the company's finances and carry out the process of privatisation.

No Brazilian industrial groups were interested in purchasing Embraer. The new shareholders were pension funds from two state-owned companies - Banco do Brasil and 
Telebrás - each of which acquired $20 \%$ of the capital - and Bozano-Simonsen a private Brazilian investment bank which held $20 \%$. The federal government set aside for itself a 'golden share' that allowed it to veto the sale of the company because of the strategic nature of this industry, responsible for a large part of the exports of high-technology goods, and because of the importance of the company in the defence sector.

In 1999, a group of French companies in the aviation and aerospace sector - Dassault, EADS, Snecma, Thales and Safran - acquired 12\% of the stock. They were the only industrial companies that had a share in Embraer's capital for several years. They withdrew in 2007. In 2001, BNDES par acquired $8 \%$ of the shares. In 2006, the Company's Board of Directors authorised the issue of shares on the São Paulo (BOVESPA) and New York Stock Exchanges (NYSE). Currently the company's capital is divided between different US and Brazilian investment funds, each holding less than $10 \%$ of the shares. No single group has shareholder control of the company.

To emerge from the crisis, the new management focused its strategy on four basic vectors, where more than US \$500 million were invested between 1995 and 1996:

1 a formal commitment to results through a strategy of financial reengineering and organisational and productive restructuring

2 the relationships with customers and suppliers through a deep commitment to the demands of its clients

3 an action plan with production restructuring and a new marketing strategy

4 Making the viability of the ERJ-145 aircraft family a top priority.

Privatisation made it possible to resume the production activities and investments in technology and to consolidate the Embraer's capacity to develop new models of aircraft. Between 1989 and 1993, when the Embraer crisis was felt most sharply, more than 2,500 employees were laid off and aircraft production was drastically cut back. A complete restructuring of the company was, therefore, an absolute necessity.

One of the main goals was to develop a new strategy for production, technology and marketing. There was a clear option to occupy market niches and strengthen the competitive capacity of the company in the world market. This implied a structural reform of the ways in which aircraft were produced, with increased investment in R\&D, acquisition of technology and the adoption of a more global sales strategy (João and Fischman, 2004).

\subsection{A new production strategy: 'families' of aircraft and risk partners}

The Embraer's production capacity has been characterised by a series of highs and lows (Vertesy and Szimai, 2010). The positive sales performance achieved from 1998 to 2001 was interrupted in 2002 and 2003 when the terrorist attack of September 11, 2001 shook the air transportation industry and led airline companies to drastically cut back their orders. At the end of 2003, a new cycle of expansion began, lasting until 2008, when the worldwide

financial crisis caused the cancellation of a large number of orders and a loss in sales of around US $\$ 700$ million.

Privatisation did not solve all the problems, but it did create the conditions for a new cycle of growth. In the second half of 1980s, Embraer responded to the demands of 
regional aviation companies, identifying the segment as a market niche that had received little or no attention from large international aircraft manufacturers such as Boeing or Airbus. This choice was reinforced after privatisation. In responding to this market, between 1994 and 2000 Embraer developed and sold a family of jet powered aircraft - ERJ1354/145 - that led it to become the third largest producer of aircraft for the regional airline market worldwide (Figure 1).

Figure 1 Embraer deliveries 2002-2010 (see online version for colours)

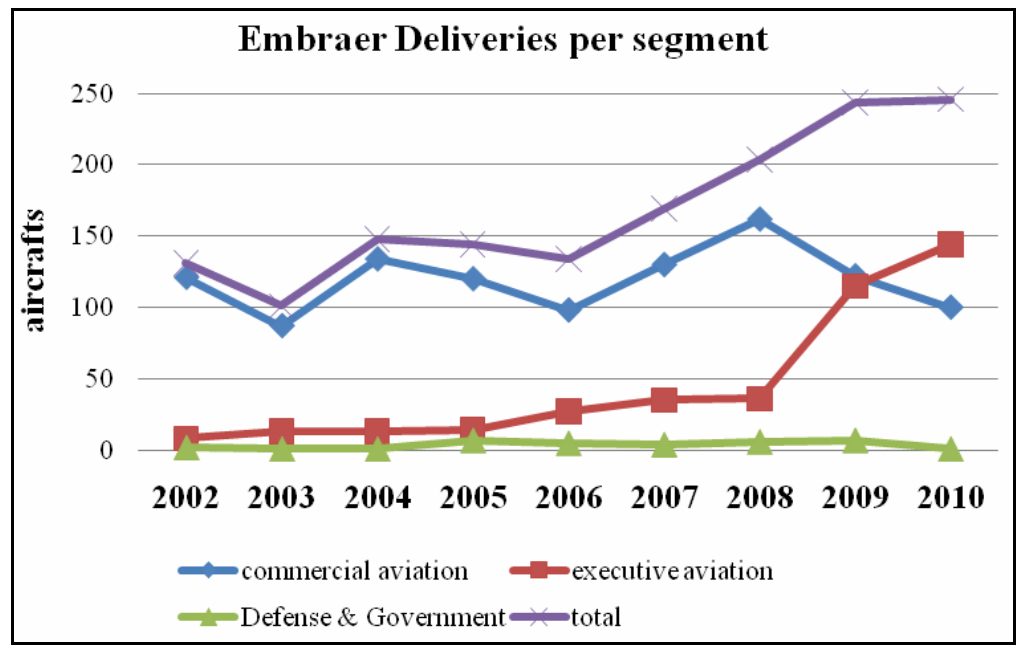

Source: Computed from Embraer annual reports

Since 2000 , the company added the corporate segment to its marketing strategy. In the defence market, orders tended to be limited in quantity and did not permit the sustained growth of the company. Nevertheless, the military orders often served to partially soften the negative impact of oscillations in the market.

Finally, with the increase in exports, Embraer expanded its maintenance and repair service activities, which had become a new source of income (11\% in 2009). Today, the firm has four maintenance centres and more than 40 authorised service centres in other countries.

\subsection{The ERJ145 and the EMBRAER 170/190 series}

Privatisation led to the adoption of a new production strategy that evolved around the development of 'families' of aircraft that favoured 'commonality'. This strategy, followed by most manufacturers, benefits the buyers because it permits lower maintenance and fleet operation costs. It is also advantageous to the manufacturer because it reduces the amount of replacement parts that need to be kept in inventory and the after sales service centres.

The Brazilian aviation industry is quite limited and Embraer is an isolated company that does not have a structured local production chain. According to the IBGE, there are 18 small companies in the aeronautics industry. The extended period of hyperinflation from 1985 to 1994 caused many small companies created in the 1970s to fail. Even after monetary stabilisation was achieved and growth resumed, these companies were not able 
technologically to meet the more and more technically complex Embraer requirements. These small companies located around Embraer in the São Jose dos Campos region were severely hit by the crises of 2001-2003 and 2008.

Embraer has its technical strengths concentrated in conception and project engineering and does not manufacture the components of its aircraft. It has resorted to outsourcing and has built a production chain based on a risk partnership with external suppliers. The network of small local companies is used only to supply simple technological inputs or for final assembly operations. The company imports the systems - avionics, electronics, hydraulics and engines - that make up the technological heart of the aircraft.

The organisation of networks of suppliers, both domestic and international, in addition to the concept of the 'family' of aircraft, was the solution that the company found to reduce the costs of development and accelerate the pace of the production process. The development of the ERJ135/145 series served as a learning process for managing risk partnerships. The same model was used for the EMBRAER170/190, which represented the second generation of jet aircraft for commercial aviation.

The ERJ145/135, which has a carrying capacity of 37-50 passengers, took five years to develop. Work on the project began in 1991 and the first airplanes were delivered in 1995. The ERJ140 and the ERJ135 are smaller versions that were manufactured until 2003. The three versions have $95 \%$ of their components in common. The ERJ145 enjoyed significant commercial success. It was the best-selling model between 2002 and 2005 and that allowed Embraer to strengthen its position in the international market. Since 1996, Embraer has produced and delivered more than 1,000 ERJs to more than 37 airlines in 24 countries. Residual sales of the aircraft continue today. Meanwhile, the ERJ145 is the basis for a military version, the EMB145, as well as the Legacy 600, introduced in 2000 as a corporate jet. Through 2008, 890 units were manufactured and it is still manufactured in China, by the joint venture Harbin-Embraer.

The development and manufacture of the ERJ145/135 series (Martinez, 2007) required the company to identify, select and coordinate a large number of offshore suppliers. Since Embraer does not manufacture any of the avionics systems, it depends on international suppliers. Embraer must therefore determine the standards and technical parameters and coordinate an extensive network of companies located in different countries. More than 40 US and European firms supplied the electrical systems (nine companies), mechanical systems (seven companies), equipment (21 companies) and metal structures (six companies) for the ERJ145. The responsibility for the later integration of the parts and subsystems is assumed by Embraer.

The company develops the conceptualisation and provides the technical specifications for each model. Some of these suppliers are called 'risk partners' because they assume, as part of the contract, a share of the investment and develop parts of the aircraft according to the guidelines and specifications stipulated by Embraer. But they also share in the earnings from sales. In addition to technical cooperation, these partnerships make easier the financing of the project. Gamesa from Spain, Sonaca from Belgium, ENAer from Chile, and C\&D Aerospace from the USA participated in the development and the manufacture of the ERJ145 series (Martinez, 2007).

The commercial success of the ERJ145 led Embraer to elaborate a new family of regional jets shortly thereafter - the EMBRAER170/175/190/195 - capable of carrying from 70 to 108 passengers. The project, announced in 1999, followed the logics of 'risk partnerships'. The first prototype of the EMBRAER170 was flown in 2002 and was 
certified and sold in 2004. Together with the ERJ series, Embraer is able to market a family of aircraft capable of transporting from 30 to 122 passengers. The new jets have a high degree of commonality with the previous series of the ERJ/145, allowing significant savings in maintenance costs for the customers. This means that Embraer is able to supply a specific aircraft model for each segment in the commuter aviation market where the company had a $49 \%$ market share in 2008 . Moreover, the regional aviation market is expanding rapidly.

The development of the EMBRAER170-195 was facilitated by the experience gained in the production of the ERJ135-145 series. The costs of development were of US $\$ 850$ million. Embraer was able to reduce the number of partnerships. Only 16 companies were selected using more rigorous criteria for technical and financial capabilities.

All of them are large international companies. Jet engines represent $20 \%$ of the cost of the aircraft. These were supplied by GE, the partner with the largest individual weight. A joint venture was formed with the German company Liebherr, which opened a branch facility in Brazil, to manufacture the landing gear, and with Kawasaki Heavy Industries to manufacture the metallic structure for the wings. The participation of small Brazilian companies was limited to the less complex components (tools and metal parts) due to their shortage of technological capability.

The coordination of the project was an extremely complex task that required Embraer to own specific skills in selecting the companies, planning their functions and coordinating in time and space the steps of the project. The formation of this network involved the de-centralisation of research activities, being carried out in plants and laboratories installed in different countries, the coordination of multidisciplinary teams and the mastery of sophisticated computing tools. A total of 600 engineers participated in this process with half of them working only for Embraer itself.

On the other hand, Embraer had to completely modernise its production process and start using 'clean manufacturing' technology. The final assembly of the E-Jets, previously made on a production in line, turned to be produced on a system of docks. The new organisation of the assembly process reduced the volume of material processed, the number of cases of non-conformity in parts and cut the total time to 12 days. But the participation of many companies, in a production chain, with a highly complex system of coordination led to delays in production and in some cases to losses of orders. This happened with Kawasaki, whose Brazilian facility was unable to meet the scheduled targets. These activities wound up being reintegrated in Embraer in 2006.

The development and assembly of the ERJ140 and EMBRAER190 family of aircraft were open to design changes in order to meet the specific needs of military aviation as well as of corporate jet aircraft. Since 2001, Embraer entered the corporate aircraft market with the Legacy programme, an executive aircraft based on the ERJ 135 platform in two versions: the Shuttle and the Executive. In 2005, the Phenom 100 was introduced. In 2009, the Phenom 300, with eight to nine seats, and the Lineage 1000, with 13-19 seats, received air certification and were ready for sale. The new model Legacy 650 was introduced in 2009 . This aircraft can carry up to 14 passengers and has a range of more than $7,000 \mathrm{~km}$. It is capable of making a non-stop flight from London to New York, from Dubai to London or from Singapore to Sydney. With these new models Embraer is able to offer seven different aircraft. The company now has a $16 \%$ share of this market segment and aspires to be the largest manufacturer in the world in this category by 2015 (Figure 2). 
Figure 2 Embraer sales per segment (2006-2010) (see online version for colours)

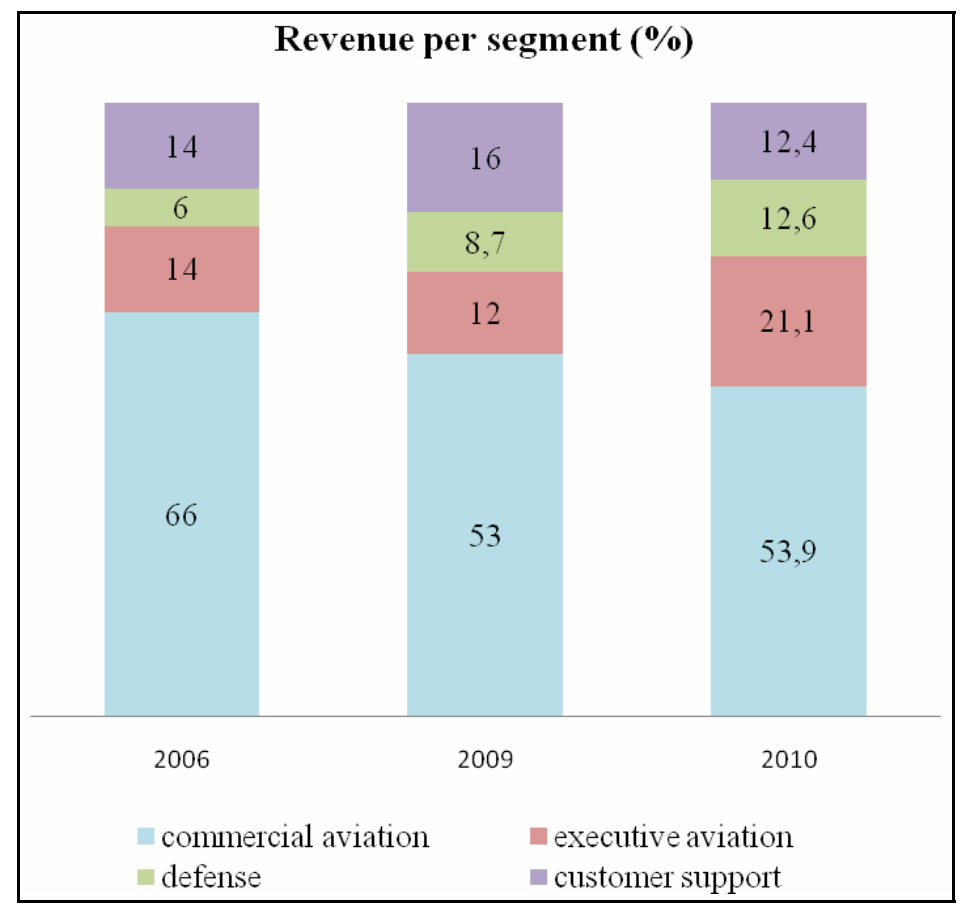

Source: Computed from Embraer annual reports

In the military aviation segment, Embraer has six models of which three were developed from the ERJ145 platform. This is a segment of aircraft that is not quantitatively significant (around 8\%) but which is considered strategic. When there are periods of softness in the orders from other segments, the Brazilian government used to formalise larger orders as a way of generating additional income for Embraer, as occurred in 2008 and 2009. Military orders are frequently accompanied by the need to develop specific technological solutions and functions as a means of financing research. The orders for 36 supersonic fighter aircraft by the FAB in 2008 are essential for the absorption of technology expected for the project F-X2. This is also the case for the order to develop the KC 390 cargo and in-flight refuelling aircraft that should make a qualitative jump possible in this market. The company considers the military market as a niche that reduces the dependency on a single segment and improves the visibility of the company in the international marketplace.

\section{The Embraer strategy for internationalisation}

Embraer is a highly internationalised company operating in various different modes. Initially, the emphasis was on technology transfer agreements, the import of embodied technology goods and equipment and, some years later, included in exports. After the privatisation, internationalisation became a featured part of the company's growth strategy. The world market was considered critical, given the limited size of the domestic 
market. The internationalisation of production and the search for association with international partners for the development, manufacture and sale of its products was designed to overcome the constraints imposed by limits to the financial, technical or administrative resources of the company. In comparison with other companies in the world aircraft industry, it should be noted that all of them are not only larger but also have much more diversified industrial production lines.

The Embraer's organisation of production is in part a response to the inevitability of its internationalisation. In the beginning, entry into the international market occurred through fairly modest exports of the Bandeirante and some military aircraft, and occurred because of the necessary after sales activities requiring the company to set up parts inventories and sales offices overseas.

With the increase in the production, these two elements - sales and services intensified. More than 18 maintenance centres were established in the USA and five in Europe. The path to internationalisation was designed to strengthen the proximity of the company to its principal buyers. Afterwards, the internationalisation strategy was able to support the entry in new markets such as in Asia.

Later on, other forms of internationalisation were adopted: subcontracting the fabrication of specific parts, joint ventures with Harbin (China) in 2003, agreements with OGMA (Portugal) in 2005, centres for inventory storage, and agreements for and with risk partners. Today the chain of production for Embraer is completely globalised, and has brought to Brazil several business partners - such as Kawasaki, Sonaca and Liebherr - that opened local production facilities.

As a result, Embraer is also responsible for almost all of Brazil's imports in the aviation sector. Imports of aircraft reactors and engines appear on the list of the federal tax authorities among the top 20 products imported by Brazil every year.

Exports, which, in 1975 were around $6 \%$ of sales, rose to $46 \%$ in 1982 and in 2010 , exports represented at least $90 \%$ of sales (Figure 3). In 2009, 46 airlines, located in 31 countries had purchased either series ERJ135-145 or EMBRAER170 airplanes. In 2008, there was an increase in the demand for used aircraft which led to an increase in the demand for replacement parts and for maintenance services and consequently to an additional income.

Figure 3 Embraer foreign and domestic sales (see online version for colours)

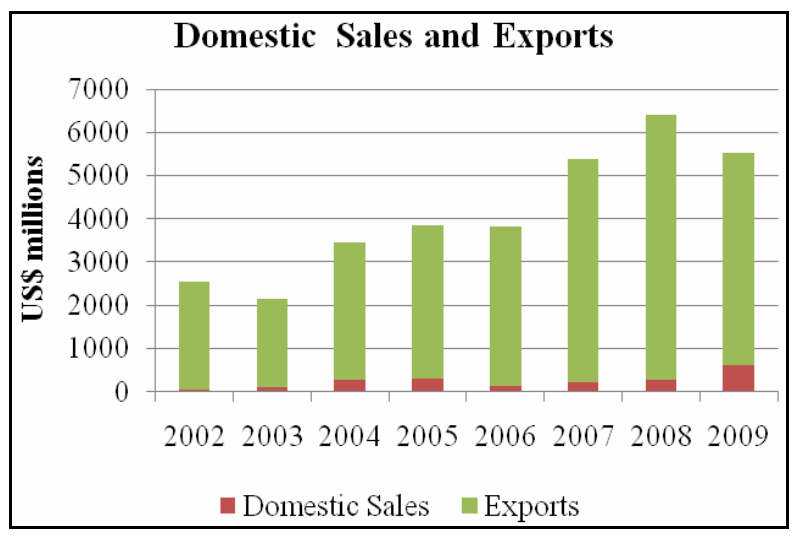

Source: Embraer annual reports 
For many years, the primary market for exports was North America - the USA and Canada. However, in 2008 and 2009, exports to the NAFTA countries fell drastically as a result of the financial crisis. With the return to growth of the US economy, this tendency should turn around. On the other hand, sales to Asian markets intensified after 2006. Embraer got new orders from China for a value of US \$2.7 bln in 2009, US \$1.4 bln in 2010 (Figure 4).

Figure 4 Embraer revenue per regions (2007-2010) (see online version for colours)

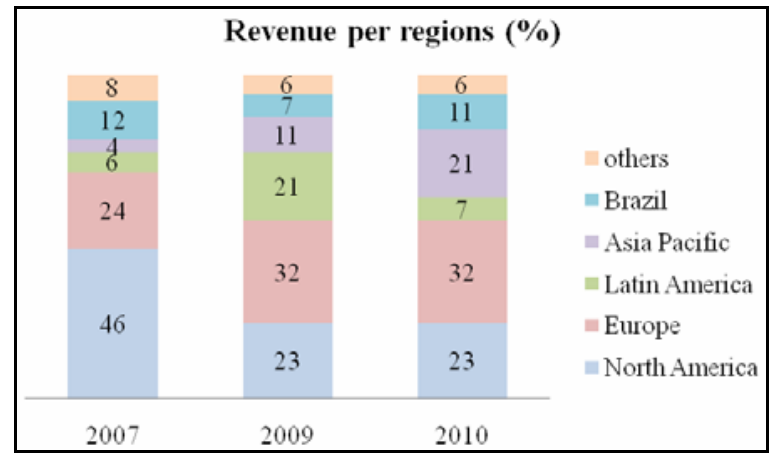

Source: From Embraer annual reports

\subsection{Marketing and R\&D strategy}

The Embraer marketing strategy is based on monitoring the trends in international market and the performance of regional airlines. At the end of the 1990s, Embraer looked carefully at the market trends in air transportation, the changes in airline company routes and their successes and difficulties and identified the potential sales represented by the growth of the 'low-cost' and 'low-fare' airlines. The E-Jet (ERJ135/145) series offered regional airlines the possibility of reducing their excess seating capacity allowing them to remain competitive during the air transport crisis.

The worldwide demand for 30 to 120 seat passenger jets is forecast to be 6,000 units over the next 20 years. That corresponds to a market of US \$200 billion. Embraer models have features that offer positive differences with other models in this market segment: comfort, low fuel consumption, low emissions levels, and low operating costs.

The current goal of the company is the growth of the EMBRAER195. This would mean that Embraer would be able to close in on products with more weight and size like the A318 developed by Airbus or the Boeing 737-600. In this market segment are also found the principal competitors in regional aviation: Bombardier and Sukhoi. At the level of the EMBRAER170/175, Embraer faces competition from Bombardier, Antonov, AVIC and Mitsubishi. The number of competitors is increasing and some of them are companies with greater production capacity than that of Embraer.

With regard to the technological training and investments in research, Embraer has strongly diversified its sources of knowledge. Investments in R\&D increased after privatisation. The transfer of technology from companies that have also become shareholders contributed to the learning process. The choice of 'risk partners' for the development and fabrication of the ERJ135 and the EMBRAER170 has this purpose in 
mind. The relationships with CTA that were essential in Embraer's early years have declined in importance. The company today has a series of technical cooperation agreements for pre-competitive research projects with research institutes and Brazilian universities. These agreements are designed to develop specific studies of a more prospective nature or to perform tests, but are not directly related to the manufacturing of aircraft.

Embraer has increased its investments in internal R\&D unevenly. Meanwhile, the concern about protection of intellectual property rights between 2003 and 2009 led Embraer to file 62 request for patents of which 14 have so far been granted. The technological trajectory of Embraer shows increased investments in R\&D until 2007 for the development of EMBRAER170/190 series. But in the last three years, the company sharply reduced its investments in research. This can delay the development of a new generation aircraft to replace the EMBRAER190 (Figure 5).

Figure 5 Embraer gross R\&D amounts (see online version for colours)

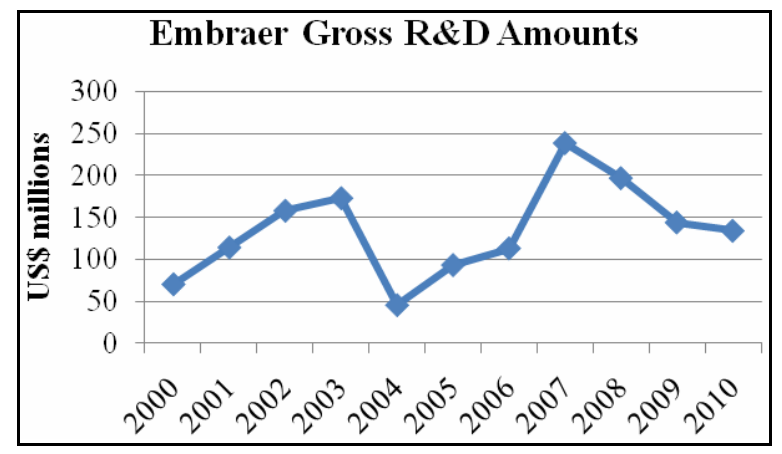

Source: Data from Embraer annual reports

Moreover, the prospect of government purchase of Rafale fighter jets from Dassault represents an important potential for learning and access to new technologies. The purchase would be accompanied by significant technology transfer. The delay in negotiations due to budget constraints blocks the possibility for Embraer to expand its technological skills.

\subsection{Factors affecting competitivity}

The growth path for Embraer is connected to some of the positive features of its aircraft price advantage, technical performance, low cost of operation and maintenance - as compared with its competitors. However. Embraer faces certain fragilities or weaknesses. Its production capacity is limited; its financial resources are scarce. It lacks a cluster of technologically capable small local companies. Its high dependence on foreign suppliers for the more complex elements of its aircraft has created an incomplete system of innovation that made it difficult to generate more radical technological innovation. The solution was a system of risk partnerships that means an open innovation process with multiple actors, each acting in its own interest (Figueiredo et al., 2008). The governance of these partnerships is nevertheless a complex task. 


\section{The challenges for Embraer and the Brazilian aircraft industry}

The growth path of the industry and its recognised international competitiveness are examples of a successful process of 'catching up'. The advantages are related to lower costs and the excellent performance and operating efficiency in a growing market niche. Government support remains critical for the company to overcome a period of vulnerability.

The high degree of internationalisation of the industry involves risks and advantages. Demand growth in Asia offers a positive outlook and the recent trade negotiations with China should ensure new orders for ERJ 145 and EMBRAER190. Nevertheless the competition in the international market is tightening considerably. There are several new entrants to the international market: companies from China, Russia and Ukraine in addition to its traditional competitor Bombardier (Goldstein and McGuire, 2004).

Thus, the Brazilian aviation industry needs to deal with several vulnerability factors. The measures proposed by the BNDES articulate the concerns of the government with the weakness in the production chain that is precariously embedded locally (BNDES, 2009). The measures to provide financial support are designed to help small companies to modernise so that they will also be able to find a place in the international market. For Embraer, the BNDES mostly offers funding to finance exports. The customs legislation was recently modified to facilitate the import and re-export of inputs purchased by Embraer and to reduce both bureaucracy and taxes.

The technological capacity of the industry is another issue that deserves to be studied by the government with greater care. Embraer is facing several challenges. In particular the company needs to increase investments in research. Embraer has completely decentralised its sources of technologically complex systems that are used in its aircraft. This situation highlights the ability of the company to choose partners and negotiate alliances. The company has managed to formulate and coordinate a complex network of international suppliers. But this also means that there is a risk of loss of control over technological solutions that are, in fact, being developed by risk partners. The appropriation of the innovation may benefit the partners in first place. If there is a problem with the fulfilment of the contracts, Embraer may find it difficult to come up with alternative suppliers.

The research carried out in public institutions is limited by the scarcity of funds invested by the government. An increase in public investment in R\&D and innovation are some of the challenges to be overcome. In recent years, many industrial companies have recognised that there is a lack of qualified human resources, and in particular a lack of engineers. Embraer has already stated publicly that it is unable to find the necessary human resources. The resumption of the space programme may also encourage investments in research and creation of new technology-based firms.

\section{Acknowledgements}

I am indebted to Brazilian CAPES and CNPq for their support of this study. I also thank the Chaire de recherche du Canada en gestion de la technologie for the help to this research project. 


\section{References}

ABDI-UNICAMP (2009) 'Relatório de Acompanhamento Setorial', Indústria Aeronáutica, December 2009, Vol. 4, available at http://www.abdi.com.br/Estudo/Aeronáutico\%20-\% 20dezembro2009.pdf (accessed on 26 May 2010).

Aerospace Industries Association of Brazil (AIAB) (2010) available at http://www.aiab.org.br/ english/index.php?option=com_content\&task=view\&id=17\&Itemid=31 (accessed on 26 May 2010).

Bernardes, R. (2003) "Passive innovation system and local learning: a case study of Embraer in Brazil', International Conference on Innovation Systems and Development Strategies for the Third Milenium, Rio de Janeiro, Globelics, available at http://redesist.ie.ufrj.br/globelics/ pdfs/GLOBELICS_0082_Bernardes.pdf (accessed on 3 November 2003).

BNDES (2008) 'Programa Indústria Aeronáutica Relatório de Acompanhamento de Execução da Agenda de Ação Atualização', Maio/2008 to Março/2010, available at http://www.pdp.gov.br/ paginas/relatorios.aspx?path=Relat\%C3\%B3rio (accessed on 26 May 2010).

BNDES (2009) http://www.bndes.gov.br/SiteBNDES/bndes/bndes pt/Institucional/Sala de Imprensa/Noticias/2009/Industria/20091126_aeronautica.html (acessed on 12 July $\overline{201} \overline{0}$ ).

Cassiolato, J.E., Bernardes, R.C. and Lastres, H. (2002) 'Innovation systems in south: a case study of Embraer in Brazil', Draft, UNCTAD-DITE Investment Policy and Capacity-Building Branch.

Dagnino, R. (1993) 'Estudo da Competitividade da Indústria Brasileira. Competitividade da indústria aeronáutica', Nota Técnica Setorial do Complexo Metal-Mecânico, MCT, FINEP, PADCT, available at http://www.docpedia.com.br/profile/dominiopublico/estudo-dacompetitividade-da-industria-brasileira---relatorio-final---vol-i (accessed on 15 April 2010).

Figueiredo, P., Silveira, G. and Sbragia, R. (2008) 'Risk sharing partnerships with suppliers: the case of Embraer', Journal of Technology Management and Innovation, Vol. 3, No. 1, pp.27-37.

Forjaz, M.C.S. (2003) 'As origens da Embraer: o projeto estratégico da aeronáutica', Relatório de pesquisa $\mathrm{N}^{\circ} 22 / 2003$, EAESP/FGV/NPP, available at http://www.http://bibliotecadigital.fgv. br/dspace/handle/10438/3051 (accessed on 15 April 2010).

Goldstein, A. (2002) "The political economy of high-tech industries in developing countries: aerospace in Brazil, Indonesia and South Africa', Cambridge Journal of Economics, Vol. 26, pp.521-538.

Goldstein, A. and McGuire, S. (2004) 'The political economy of strategic trade policy and the Brazil-Canada export subsidies saga', The World Economy, Vol. 27, No. 4, pp.541-566.

IBGE (2009) 'Pesquisa industrial', Vol. 28, No. 1, pp.1-182, Rio de Janeiro, available at http://www.ibge.gov.br/home/estatistica/economia/industria/pia/produtos/produto2009/default. produto.shtm (accessed on 26 May 2010).

João, B.N. and Fischmann, A.A. (2004) 'Estratégias baseadas no conhecimento na Embraer. Um estudo de caso', Working Paper No. 04/011, available at http://www.ead.fea.usp.br/wpapers (accessed on 29 January 2009).

Martinez, M.R.E. (2007) 'A globalização da indústria aeronáutica: o caso da Embraer', Tese de doutorado, Brasília, UNB, available at http://www.http://repositorio.bce.unb.br/handle/ $10482 / 2931$

Pereira, M.F.V. (2007) 'Trajetórias da industria aeronáutica no território brasileiro - Embraer S/A: do projeto geopolítico militar à produção globalizada', Caminhos de Geografia Uberlândia, February 2007, Vol. 7, No. 20, pp.102-112, available at http://www.ig.ufu.br/revista/ caminnhos.html (acessed on 15 April 2012).

Vertesy, D. and Szirmai, A. (2010) 'Brazilian aerospace manufacturing in comparative perspective: Brazil/USA comparison of output and productivity', Working Paper Series UNU-MERIT, Working Papers 032-2010, available at http://www.merit.unu.edu/staff/szirmai/Cvaszir.pdf (accessed on October 7 2010).

Viotti, E.B. (2002) 'National learning systems: a new approach on technological change in late industrializing economies and evidences from the cases of Brazil and South Korea', Technological Forecasting \& Social Change, No. 69, pp.653-680. 